\title{
The representation of the rural exodus in Spanish cinema (1900-2020): evolution, causes and territorial consequences
}

\author{
La representación del éxodo rural en el cine español (1900-2020): \\ evolución, causas y consecuencias territoriales
}

\author{
Antonio Martinez-Puche ${ }^{1^{*}}$ \\ Salvador Martínez Puche ${ }^{2}$ \\ Francisco Javier García Delgado 3 (D) \\ Xavier Amat Montesinos ${ }^{4}$ (i)
}

\begin{abstract}
Rural depopulation has been a constant feature of contemporary Spanish history and has been amply studied from the perspective of geography. Recently, however, there has been considerable media attention given to the consequences of internal migration. Behind the alarming demographic statistics lies a nexus of processes which have been reflected in the cinema since its beginning. This paper explores these processes at work in the rural sending environment and receiving urban destination through an analysis of six representative Spanish films. The fictional representation through film of a complex reality provides insights into the internal and contextual keys to understanding the phenomenon of 'empty Spain' or 'hollowed-out Spain'. The films illustrate the persistence of two conflicting ideas (the rural and urban), divergence about what constitutes development and the quality of life, and the processes leading to 'demotanasia'.
\end{abstract}

Keywords: depopulation; migration; 'demotanasia'; cinema and territory; rural drama; ageing.

\section{Resumen}

La despoblación rural ha sido una constante en la historia contemporánea de España, y ha sido ampliamente estudiada desde la perspectiva de la Geografía. Sin embargo, en los últimos tiempos se ha prestado una gran atención mediática a las consecuencias de las migraciones interiores. Detrás de las alarmantes estadísticas demográficas se esconde un nexo de procesos que se han reflejado en el cine desde sus inicios. Este trabajo explora estos procesos en funcionamiento en el entorno rural de envío y en el destino urbano de recepción a través del análisis de seis películas españolas representativas. La representación ficcional a través del cine de una realidad compleja permite conocer las claves internas y contextuales para entender el fenómeno de la "España vacía" o "España vaciada". Las películas ilustran la persistencia de dos ideas contrapuestas (lo rural y lo urbano), la divergencia sobre lo que constituye el desarrollo y la calidad de vida, y los procesos que conducen a la "demotanasia".

Palabras clave: despoblación; migración; demotanasia; cine y territorio; drama rural; envejecimiento.

\footnotetext{
1 Department of Human Geography. University of Alicante, Spain. antonio.martinez@ua.es. * Corresponding author

2 Department of Communication. University of Murcia, Spain. s.martinezpuche@um.es

3 Department of History, Geography and Anthropology. University of Huelva, Spain. fcogarci.uhu@gmail.com

4 Department of Human Geography. University of Alicante, Spain. xavier.amat@ua.es
} 


\section{Introduction: cinema and the depopulation of Spain, development, and socio-territorial repercussions}

Although Spain suffered the process of rural exodus/depopulation later than other regions of Western Europe, the process was more intense and rapid, and its effects (in terms of development/evolution and distribution) have persisted into the present time. The political, ideological, and socio-economic transformations which Spain underwent at the turn of the nineteenth century, and more significantly in the second half of the twentieth century, resulted in widespread territorial changes in the demographic distribution. These shifts can be seen most clearly in the changing patterns of settlement and productive occupation, as well as through examination of the transport networks, basic infrastructures, and telecommunication systems. According to the 1860 Census, $62 \%$ of the workforce in Spain was employed in the primary sector (owners, tenants, and farm labourers) (Gozálvez Pérez and Martín-Serrano, 2018), while in 1950 the figure was slightly above 48\% (Spanish Statistical Office [INE], 1950). The population of Spain went from being predominantly rural until the 1960s to agriculture accounting for little more than 30\% by the year 2000 .

Over the last few years, the phenomenon of 'empty Spain' or 'hollowed-out Spain' - a phrase used to refer to the acute rural depopulation affecting large swathes of the country - has attracted increased media attention and has become the focus of academic studies from a range of perspectives. Studies such as those by Reher (1999), Sarasúa (1994) and Dubert $(1998,2002)$ have shown different patterns of rural-urban migration, both temporary and permanent, while Florencio and López Martínez (2000a, 2000b) have studied intra-rural migration associated with agricultural work. Studies into the different types of preindustrial migration during periods and within specific regions have also been reviewed in Eiras and Rey (1994), González Portilla and Zarraga (1996), and Rodríguez Galdo (1999), Roquer and Blay (2008), Collantes, Kerstin and Prados (2016), Reques Velasco (2017) and Camarero (2020). These authors have examined other factors beyond territorial migrations from rural to urban areas and vice-versa, such as low fertility rates, male-skewed sex ratios and the ageing population in rural contexts. This study examines how socio-demographic, economic, political, and ethnographic aspects of the rural flight in Spain have been presented (and represented) in a selection of six films. By doing so, the research aims to shed light on the causes and consequences of depopulation, as depicted by the cinema of the time.

Three chronological periods were established to bring the object of the study and its context into focus. These period do not represent an equalisation of homogeneous periods (same duration, for example), so much as coherent grouping of relevant socio-economic, demographic, and political situations that imply structural and substantial changes in the evolution of migrations and the evolution of depopulation:

a) From 1900 to 1960. The imaginary of the rural world, popular folklore, and socioeconomic reality

This section shows the dichotomy 'rural misery' versus 'urban progress'. The population of Spain increased steadily from 1900 to 1930 , albeit with numerous regional discrepancies and cities grew (Barcelona and Madrid, each with populations of over half a million in 1900, achieved an accumulated growth of over $40 \%$ by 1930). The population went from 18,594,404 inhabitants in 1900 to $23,563,867$ three decades later (representing an annual growth rate of $0.9 \%$ ), a growth shared by most of the national territory, with the exceptions of rural areas in Malthusian Catalonia ${ }^{5}$ and the two Castille provinces (Reques Velasco, 2017). Essentially, there were substantial differences between different areas in rural Spain. Most municipalities in rural Castille-Leon, those of the Pyrenees/Pre-Pyrenees, and the interior southern Mediterranean, together with Murcia and Almeria, generally displayed a marked pattern of return, while other regions, notably Castilla-La Mancha, Extremadura, and Andalusia, experienced a sharp increase in emigration from the second half of the twentieth century onwards (Figure 1). The patterns of internal migration associated with the ruralisation of the Spanish economy that took place during the 40s - that is to say, migrant workforces returning to their original regions - have been very poorly studied, in part due to the lack of reliable sources, but also because the period represents an 'atypical' pattern going against the trend of rural depopulation which had prevailed since the last quarter of the nineteenth century. Whatever the case, migration figures (for example, García Barbancho, 1967), along with the estimates for net rural migration in Leal, Leguina, Naredo and Tarrafeta (1986), show that, over the course of the decade, the overall rate was negative (in other words, there was net rural depopulation), albeit relatively modest in comparison with previous decades. This trend underwent a substantial change in the 1950s. With just a few exceptions, there was a marked increase in the drift to cities and regional capitals. At the same time,

5 This expression, derived from the name of the economist Thomas Robert Malthus, is a synonym for impoverished because of demographic, socio-political, and economic factors. 
the population of rural areas, which had remained stable since the beginning of the century, showed little or no growth during the decade. During this period the proportion of young people constituting the rural population was also high, until the stabilisation plan and its consequences, known as 'developmentalism', began to take effect. These processes are analysed in both the 1930 and 1942 versions of The Cursed Village (La aldea maldita) by Florián Rey and in José Antonio Nieves Conde's 1951 Furrows (Surcos).

Figure 1. Density and evolution of the population in Spain (1900-1960)

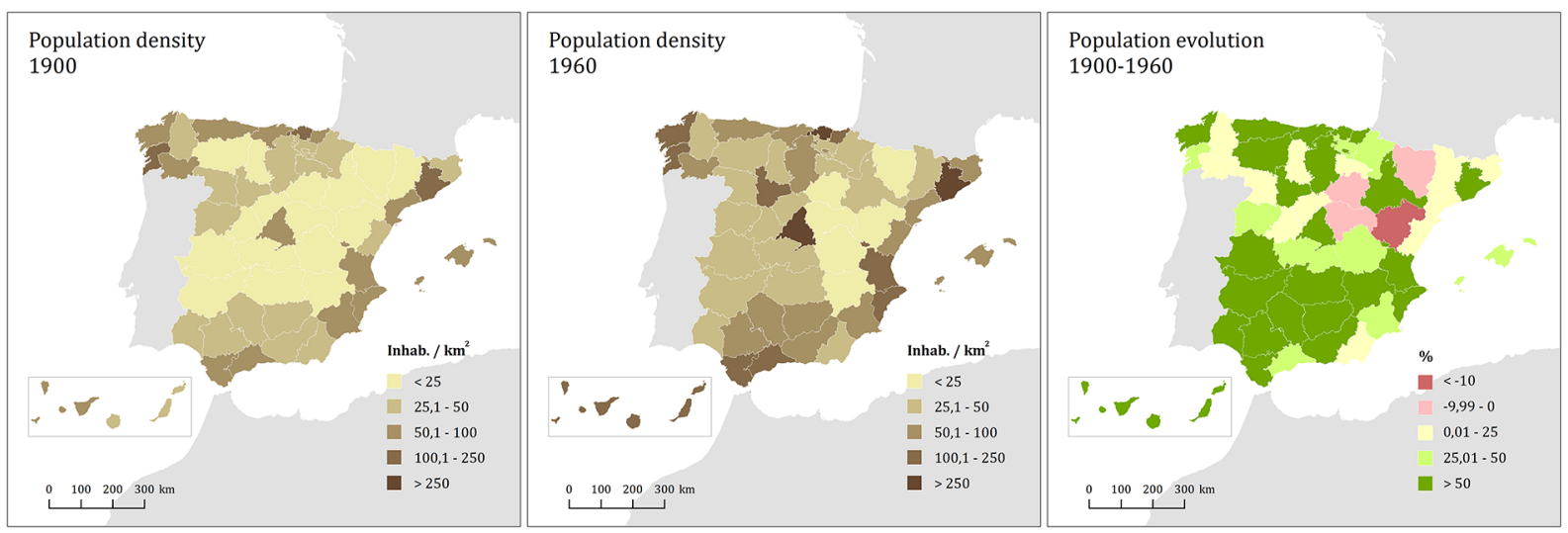

Source: INE. Population and Housing Censuses (1900 and 1960). Own elaboration

b) From 1960 to 1981. Increasing migration from rural to urban areas

This section shows socio-demographic and territorial effects on the Mediterranean coast under the influence of the stabilisation plan. In the 1960s rural Spain underwent a short but intense period of depopulation ('rural exodus'), the main consequence of which was to leave an ageing population with diminished possibilities for replenishment. From being a chiefly agrarian country, Spain rapidly became industrial and urban. It was a process that had occurred in much of Europe during the nineteenth century, and when it reached Mediterranean Europe a century or so later it was especially intense (Figure 2). The resulting territorial shifts were acute, particularly between inland rural areas and coastal towns (Reques Velasco, 2017) with only Madrid and a handful of provincial capitals and regional centres proving the exception. This pattern of internal migration was most notable once emigration outside Spain subsided. Madrid, Barcelona and, to a lesser extent, Seville and the Basque Country were the main destinations, drawing in migrants from a limited number of generally adjacent feeder provinces (Silvestre, 2010). Coastal areas saw rapid development thanks to the growth of tourism and the socio-economic changes taking place in the municipalities along the Mediterranean, brought about by the influx of migrants from rural areas and tourists from the rest of Europe. The period, and the processes driving the tumultuous changes, are well-reflected in the films La piel quemada ('Sunburnt' by Josep María Forn, 1967), and El turismo es un gran invento ('Tourism is a great invention', by Pedro Lazaga, 1968).

Figure 2. Density and evolution of the population in Spain (1960-1981)

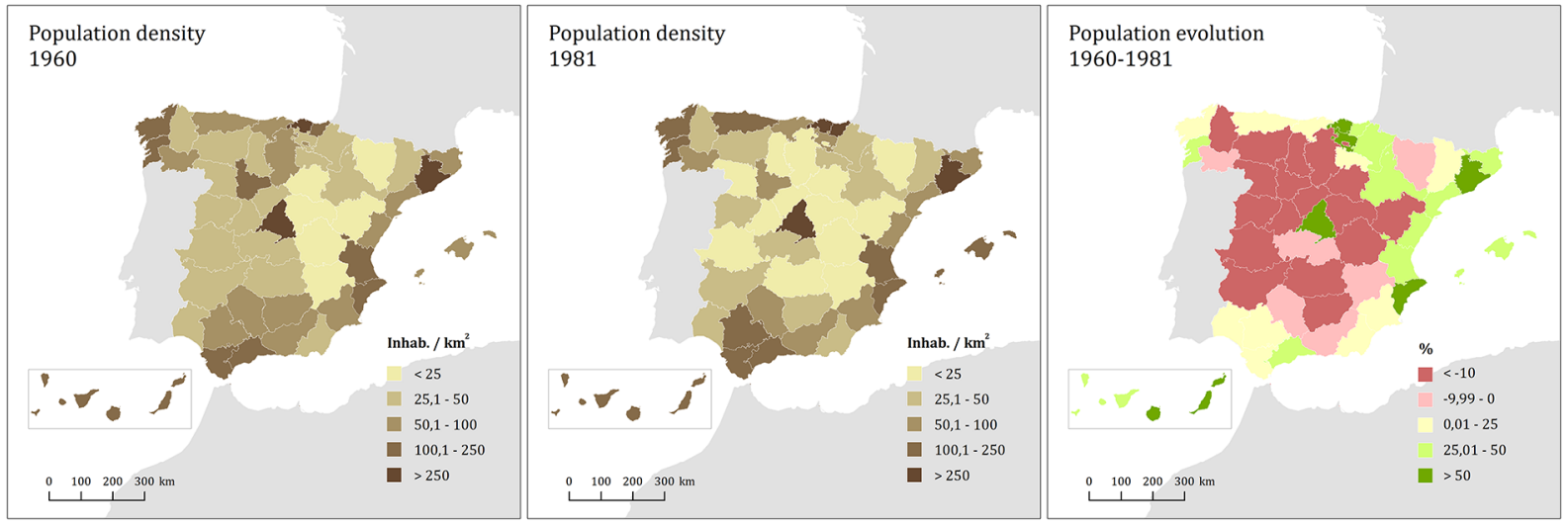

Source: INE. Population and Housing Censuses (1960 and 1981). Own elaboration 


\section{c) From 1981 to the present}

This section shows the new influxes and confirmation of the demographic, economic, and cultural fault lines around 'migrants, town and country'. This period witnessed the widening rift between the rural and urban environments in both the socio-economic and cultural spheres, a situation made more complex by the influx of migrants from outside Spain. These issues were especially felt from the beginning of the 1990s, when new contextual and cultural identities (such as urban vs rural, Latin American vs Maghreb) raised the prospect of a multicultural Spain. The film Flowers from Another World (Flores de otro mundo by Icíar Bollaín, 1999) examines the challenges of assimilation through the story of a farming town which 'imports' a group of marriageable women in a bid to halt its decline, a measure that plays out with mixed success.

The decade from 2001 to 2011 can be considered a period of re-equilibrium based on the phenomenon of peri-urbanisation, giving rise to new trends in residential behaviour, facilitated by private transport and communication infrastructures. This resulted in a progressive demographic emptying of the central areas of urban municipalities, halted only by the arrival of foreign immigrants, who also took up residence in rural areas. Significantly, the data from 2006 show that municipal areas of between 2,000 and 10,000 inhabitants (the conventional limits in Spain for defining municipalities as non-urban or 'intermediate') had increased their population on average by over 750 people in the previous decade, which represented a marked change in tendency after a long period of decline and exceeded the national average. Of greater interest, as Roquer and Blay (2017) point out, is that in the second half of the same period, the municipalities of between 500 and 2,000 inhabitants (those considered truly rural by the NSI) also achieved growth rates, after having registered negative figures in the first five years, suggesting a widespread territorial demographic 'recovery' for the period in question (Figure 3).

Figure 3. Density and evolution of the population in Spain (1981-2020)
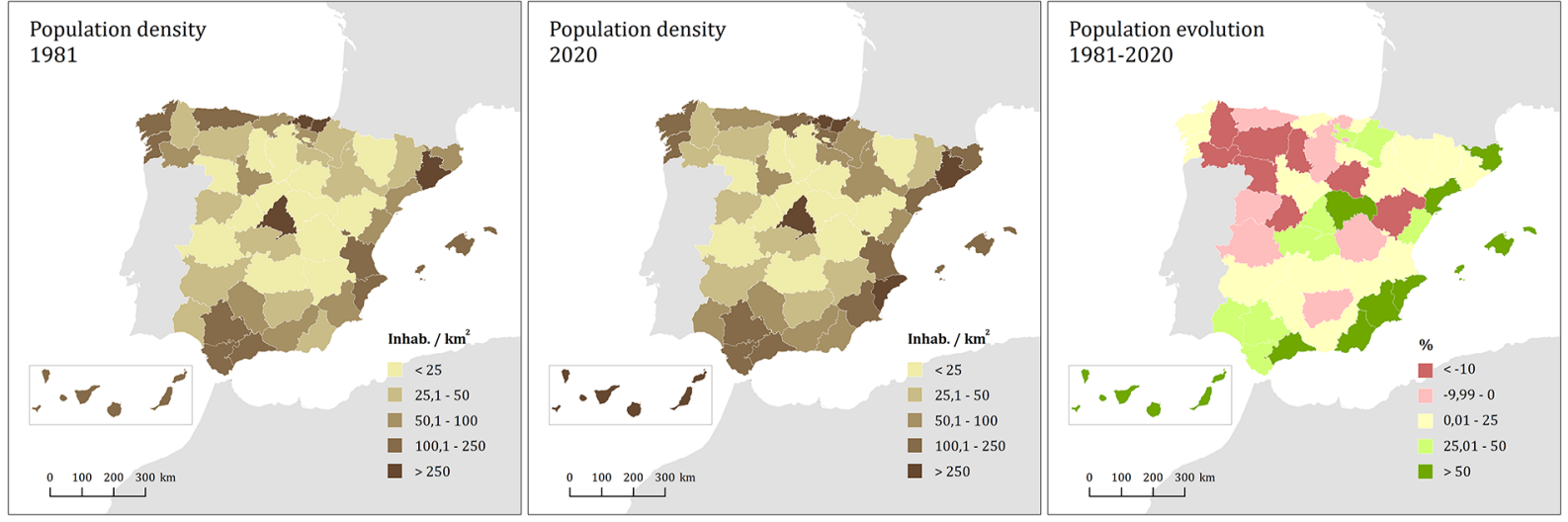

Source: Instituto Nacional de Estadística INE. Population and Housing Censuses (1981) and Revision of the Municipal Register (2020). Own elaboration

Current demographic trends highlight many of the phenomena mentioned above. The hollowing out of the interior reflects the large number of municipal districts with a population density of $<23 \mathrm{hab} . / \mathrm{km}^{2}$, located primarily in the two mesetas, the Iberian System, the Sierra Morena, the Pre-Pyrenees, and inland Galicia (Reques Velasco, 2017). The exodus that took place during the 60s and 70s of the last century, coupled with the current ageing population and falling birth rates, have resulted in a deep-rooted economic stagnation and an interminable dwindling of the population, driving many municipalities to critical population density thresholds, and leading the research community and the media to coin the phrase 'demosthanasia' (Cerdá, 2017; Burillo, Rubio and Burillo, 2019). This situation was brought to the screen in the film El violin de piedra ('The Stone Violin' by Emilio Ruiz Barrachina, 2015).

\section{Methodology}

The French writer Jean Giono once said that 'to imagine is to choose'. Here, we invert the dictum and arbitrarily chose works of the imagination that travel in both directions: celluloid narratives that transcend the screen to become reality and lived realities which become cultural landmarks when they are brought to the screen - in short, the intersection of cinema, rural life, and depopulation. The criteria 
are based on three systematic aspects: thematic (depopulation and rural emigration), synchrony (representation of the sociocultural and economic context of the moment), and diachrony (temporal evolution according to the adequacy of the established historical periods).

To capture a sufficiently wide perspective with regard to the origins and development of the topic six feature-length films were selected from various periods: La aldea maldita ('The Cursed Village') (1930, 1942), Surcos ('Furrows') (1951), La piel quemada ('Sunburn') (1967), El turismo es un gran invento ('Tourism is a Great Invention') (1967), Flores de otro mundo ('Flowers from Another World') (1999) and El violin de piedra ('The Stone Violin') (2015). The films were compared for events, likenesses, and differences in terms of plot, style, and themes. Each is of its time and while reflecting differences at both the narrative and formal levels, they also draw on a taxonomic pool recurrent in Spanish cinema. The range includes rural drama, neorealism depicting pre-democratic socio-political issues, a comedy set in the 'economic miracle' of the late Franco period, an existential retrospective on the effects of migration from the end of the twentieth century, and a blend of the humorous with more personal poetic and artistic expressions.

In each case a mirror is held up to the nature of rural life, creating and sustaining what has been termed the social imaginary:

The imaginary is a variegated repertoire of images shared by a society or social group, the space which holds the objectifications of the collective imagination. The imaginary comprises the representations, evidence and implicit normative assumptions which configure the group imagines the world, social relationships, the group itself, social identities, the collective goals, and aspirations and so on. (Abril, 2007, p. 62).

The films were analysed according to a social semiotic perspective which combined the systems in Verón (1987) and Rodrigo Alsina (1995) and identified discourse and extra-discourse variables. The latter category included technical and cast credits, a synopsis, source (original screenplay or adaptation from literary work), prizes and awards, and critical reception (Table 1).

Table 1. Discourse variables for cinematic analysis. Depopulation and the rural context

\begin{tabular}{|c|c|c|}
\hline Visual realisation and sound & Narrative and plot & Axiological elements \\
\hline $\begin{array}{l}\text { * Spatial-temporal setting } \\
\text { (representation of places in terms } \\
\text { of location and historical time). } \\
\text { * Use of photography, light, frames, } \\
\text { and shots (visualisation of rural } \\
\text { space). } \\
\text { * Notable dialogue referencing } \\
\text { aspects of the rural experience. } \\
\text { * Sound effects and soundtrack } \\
\text { (evocative power of the } \\
\text { soundscape). }\end{array}$ & $\begin{array}{l}\text { * } \text { Film genre. } \\
\text { Characters: description of } \\
\text { individual physical, sociological } \\
\text { and psychological character- } \\
\text { istics, plus relationships between } \\
\text { them (lead and support roles). } \\
\text { * Summary of plot and context } \\
\text { of rural discourse in film: plot } \\
\text { development and character arcs, } \\
\text { conflicts, and key moments in } \\
\text { narrative. } \\
\text { * Elements in story representing } \\
\text { the rural experience from } \\
\text { denotative point of view } \\
\text { (descriptive, what it is) and } \\
\text { connotative (interpretative, what } \\
\text { it represents). }\end{array}$ & $\begin{array}{l}\text { Specific: Representation } \\
\text { of sociocultural values of } \\
\text { characters and their milieu: } \\
\text { * Deployment of rural stereotypes } \\
\text { and tropes. } \\
\text { * Deep-rooted values, traditions, } \\
\text { habits, and customs. } \\
\text { General: Themes concerning the } \\
\text { rural experience: } \\
\text { * Depopulation and ageing. } \\
\text { * Individual and group identity. } \\
\text { * Access to education and levels of } \\
\text { education. } \\
\text { * Lack of services and public } \\
\text { investment. } \\
* \text { Scarcity of socioeconomic-work } \\
\text { opportunities. } \\
\text { * Erosion of a way of life and sense } \\
\text { of loss. }\end{array}$ \\
\hline
\end{tabular}

Source: Verón (1987) and Rodrigo Alsina (1995). Own elaboration

According to Morin (1970), writing about popular culture, the signification and cognitive function of a film is determined by theme, genre, aesthetics, and style, through the interplay between its semantic structure (the what: the signification of archetypes) and its representation of the everyday (the how: the formal dimension of communication). This is to say that 'certain forms can never be the vehicle of certain 
meanings, in the same way that certain meanings can never embodied by certain forms' (Zunzunegui, 2005, p. 14). Nevertheless, it is not possible to identify a 'rural' subgenre of films. Cinema is by nature heterogeneous, iconoclastic, and eclectic. Underlying these films is the dichotomy of rural versus urban as a heterogeneous expression from the plot and contextual point of view (Gómez and Poyato, 2010).

It encompasses the political polemic of Luis Buñuel and his Las Hurdes, tierra sin pan (Land Without Bread) (1993), the absurdist humour of José Luis Cuerda's Amanece, que no es poco ('It's sunrise, which is no small thing') (1989) which defies classification, the meticulously observed existential work of Carla Simón in Verano 1993 (Summer 1993) (2017), Jorge Sánchez-Cabezudo's tense thriller La noche de los girasoles (The Night of the Sunflowers) (2006), and Pedro Almodóvar's hilarious dissection of everyday life in La Mancha in Volver ('Coming home') (2006).

One of the Spanish directors who has had most influence on how rural life is portrayed on screen, Montxo Armendáriz, has distanced himself from any kind of deliberate rural aesthetic. In an interview with Heredero and Reviriego (2009) in 'Cahiers du Cinema' about his 1984 film Tasio, which follows the fortunes of a Navarrese coalman, he stated: 'I wasn't particularly going for a portrait of rural life. If I'd found a character of that ilk in another sphere - in a town or in a factory - I'd have been interested in just the same way' (p. 10-21). As Sánchez Navas (2012) points out:

not even the creators themselves ascribe to a notion of ruralist cinema; instead, they admit that the starting point of all cinema is about the eternal laws governing the story, which concern the narrative and the conflict of human beings with the environment and with each other. (p. 191-192)

A difficulty arises when it comes to delimiting the characteristics common to a film production, which compels us to focus not so much on the rural experience and its circumstances per se, as on the rural experience on film and specific representatives of this.

\section{Results}

\subsection{From 1900 to 1960. The imaginary of the rural world, popular folklore, and socioeconomic reality}

The urban population, defined as municipalities whose total number of inhabitants exceeds 10,000, accounted for $31.78 \%$ of the Spanish population in 1900 . By the 1960 s this had risen to $56.57 \%$ at the expense of rural communities. Expressed inversely, this means that at the start of the twentieth century over two-thirds of the population (68.22\%) lived in the country, and that this proportion had declined to well under half (43.43\%) within sixty years (Capel, 1967).

\subsection{1. 'The Cursed Village' (1930-1942) and the popular imaginary of rural experience}

This rural drama directed by Florián Rey, such was the success of the film when it was released in a silent version, that it was later remade as a talking picture. The two films are nevertheless identical visions of the same experience and cannot be considered as distinct entities. The Venice Film Festival awarded this latter version a Biennale Medal that year, and it also won the first prize awarded by the National Entertainment Union (Sindicato Nacional del Espectáculo), which had been set up the same year. The idea for The Cursed Village arose during filming scenes for the film Los chicos de la escuela ('The schoolboys') (1925) on location in Pedraza (Segovia). Florián Rey became fascinated by the vicissitudes of the town, which had drastically shrunk from 15,000 to just 500 inhabitants within a century and a half, because of the harsh climate which had repeatedly devastated crops and forced generation after generation to abandon their home. So appalled was he that he wrote the screenplay in just a week, which he managed to bring to the screen in 1930. It is considered by many to be his most successful and celebrated film (Sánchez Vidal, 1987). The first version of The Cursed Village was filmed on a budget of 22,000 pesetas provided by Florián Rey himself and Pedro Larrañaga. The scene of greatest impact is that of the villagers leaving in their carts, a scene later reproduced with greater means and in more detail in the 1942 ver$\operatorname{sion}^{6}$ (Sánchez Vidal, 1987). The lead roles in the first version were played by Carmen Viance and Pedro Larrañaga, while the same roles were played by Florencia Bécquer and Julio Rey de las Heras in the 1942 remake.

6 The 1942 version managed to raise a budget of 1,050,000 pesetas. 
The silent version opens with the intertitle 'Over the ruins of Castille' and the words: 'They say that the heavens wished to punish the small Castilian village. For this reason, the earth denied the village its fruit. On seeing the bell tower, everybody made the sign of the cross'. In addition to foregrounding various aspects of rural life, the film presents the viewer with a familiar situation of the time, which had been dealt with in melodramatic fashion in other films that focused particularly on elements of local tradition and lore. Here the treatment is emblematic. The theme of female sexual honour is represented in the role of the wife who abandons her husband to go to the town and is forced to 'corrupt herself' in prostitution to survive. It also one of the few films, along with La bodega (Wine Cellars) (Benito Perojo, 1929) to talk frankly about the social precariousness of life in rural Spain. In its representation of the communion with nature, it is reminiscent of Murnau, but also bears comparison with the contemporary Soviet cinema and its denunciation of the Tsarist exploitation of the peasantry (Gubern, 2007).

Table 2. Discourse variables for cinematic analysis, The Cursed Village

\begin{tabular}{|c|c|}
\hline \multirow[t]{2}{*}{$\begin{array}{l}\text { The Cursed Village } \\
\text { (1930 and 1942) }\end{array}$} & VISUAL AND SOUND ASPECTS \\
\hline & $\begin{array}{l}\text { Narrative space: Luján. } \\
\text { Locations: Pedraza de la Sierra, Ayllón and Sepúlveda, Segovia (1930) and Salamanca (1942). } \\
\text { Historical time: 30s s. XX (1930) and year } 1900 \text { (1942). } \\
\text { Image: Black and white. } \\
\text { Photography: Expressionist influence and Soviet cinema on the view of nature. Periodic labeling } \\
\text { (30). Historicist labeling (1942). } \\
\text { Dialogues and labels: Featured in this paper. Silent movie (1930) and talking picture (1942). } \\
\text { BSO Extradiegetic: Piano folk evocation and classical setting (30). Diegetic: Popular carol } \\
\text { orchestrated with dances at the beginning (1942). }\end{array}$ \\
\hline & NARRATIVE AND PLOT ASPECTS \\
\hline & $\begin{array}{l}\text { Film genre: Drama (1930) and melodrama (1942). } \\
\text { Character: Juan Castilla, his wife Acacia, and his blind father. 'Tío' Lucas, the boss or patron of } \\
\text { the clientelist social structure, (1930) is replaced by the figure of the moneylender (1942), but this } \\
\text { character has no influence on the plot. The first version presents Juan as a simple peasant labourer, } \\
\text { tilling the land; in the second, by contrast, he is comfortably off with his own land, and has acquired } \\
\text { a brother for the purpose of introducing the theme of the 'two Spains'. In the first version, when } \\
\text { Acacia escapes to town, she is forced into prostitution, while in the second, complying with the } \\
\text { mores of the time, she finds work in the cabaret, and seeks the obligatory forgiveness in the final reel. } \\
\text { Summary plot and context: Years of poor harvests have brought misery to the village of Luján in the } \\
\text { region of Castilla. When the harvest is once again destroyed by storms, the villagers have no choice } \\
\text { but to head to the town in search of better living conditions. Juan Castilla has a dispute for which } \\
\text { 'tio' Lucas goes to jail, thus precipitating Acacia's decision to abandon her husband and son and seek } \\
\text { a better life in town. } \\
\text { Rural elements in story: The hunger and misery suffered by the villagers, powerfully evoked in the } \\
\text { first version by the scene of the cat seen disappearing into its lair, from which only bones are later } \\
\text { taken out, are rendered in the second with saccharine whimsy and little naturalism. }\end{array}$ \\
\hline & AXIOLOGICAL ASPECTS \\
\hline & $\begin{array}{l}\text { Specific: Hunger (context) and honour (plot). Religion and family. Urban perversion (1930). } \\
\text { Precariousness and agricultural exploitation (1930). Morality and traditional and national-catholic } \\
\text { content (1942). } \\
\text { Ethnographic and social dimension (1930). } \\
\text { General: Individual and group identity, scarcity of socioeconomic-work opportunities, erosion of a } \\
\text { way of life and sense of loss. }\end{array}$ \\
\hline
\end{tabular}

Own elaboration

Under the shadow of Catholic Nationalism, the 1942 version gave a very different treatment to the story than its predecessor, turning up the melodrama and toning down the social and ethnographic commentary. The most significant change, occasioned by the intervening Civil War, is the relocation of the setting to 1900. The original was contemporaneous with the events it depicted on the cusp of the Second Republic in the last days of a failing monarchy. In the 1942 version, the opening credits clearly signal that the film is a "Cinematographic poem», and an intertitle locates the events in the past: 'When towns became disconnected from the fields that provided for them, they left the labourer unprotected in his struggle against the unfavourable elements. In consequence, abandoned villages, mass emigration and 
rural flight drained the lifeblood of the nation'. And for there to be no doubt that what audiences were about to see was definitively in the past, the typeface was gothic throughout. The result is that the film takes on a folkloric, almost archaeological tone, which greatly distances it from the 1930 version, which had a contemporary and lived feel to it, and certainly did not shy away from using a standard news typeface of the time. Worse, the film is divided into four sections, each one a kind of miniature painting of some bygone era with the players window-dressed in outmoded costumes from the province of Segovia. The acting is unrelentingly wooden, punctuated with starched mannerisms that give the film an archaic and papier-mâché aesthetic (Zumalde Arregui, 1999).

Stylistically, the first version is more suggestive and stripped down, with fewer characters and shot sequences, whereas the second is characterised by a religiosity that displaces the human dimension. Thus, for example, Acacia's return and repentance is heavily prefigured by church bells and the villagers preparing for the patron saint's day celebrations.

\subsection{2. 'Furrows' (1951): the gulf between town and country}

This 1951 film, directed by José Antonio Nieves Conde from a screenplay by Gonzalo Torrente Ballester (adapted from Eugenio Montes and Natividad Zaro's original script), was considered by contemporary critics as being in the style of Italian neorealism (albeit muted by Francoist restrictions), as can be seen in various scenes styled according to the escapist cinema then prevailing in Hollywood. The film can be interpreted in various ways (post-war cinema, neorealist drama, political commentary, or even semi-documentary), but what is undeniable is that 'Furrows is a slice of living Spanish history' (Castiello, 2010).

Nieves Conde's direction received substantial critical acclaim, and the film won prizes in four categories in the $7^{\text {th }}$ Cinema Writers Circle (best film, best director, best supporting actor, and best supporting actress). The National Entertainment Union also awarded it third prize in the Best Film category, and it was declared of 'National Interest' by the Ministry for Information and Tourism, giving it the right to maximum protection. García Escudero, a Falangist who was named Director General of Cinema and Theatre the same year as the film's release, certainly saw in it welcome signs of a change of direction by a previously stagnant industry with regard to patriotic, folkloric, and popular themes.

The film has been likened to other neorealist Spanish films of the time, particularly those where the Regenerationist and naturalist influence ${ }^{7}$ are more visible than the neorealism, such as Welcome, Mr Marshall! (Bienvenido, Mister Marshall!) by Luis García Berlanga. In both there are glimpses of post-war Italian cinema, but more significantly each is infused with a disenchanted Falangist ideology - indeed, Berlanga's immortal work, produced by Uninci had various Falangists in the production team, such as the brothers Joaquín and Alberto Reig (Sojo Gil, 2011, p. 104).

According to the director, the film was conceived of as an updated continuation of the first version of The Cursed Village (1930). A pall of pessimism and fatalism certainly hangs over the film, and for all its neorealist aesthetic, there is a strong vein of Cervantes running throughout (Sojo Gil, 2011).

The context in which the film was produced is fundamental. The project started life as an idea by Eugenio Montes (one of the founders of the Falange Española), among the hardcore Falangists known as the 'old shirts' (on the left wing of the Falange movement), who felt betrayed by Franco's 'New Spain'. They felt that the new regime had done nothing to tackle the old problems, which had become more acute in some towns because of the steady influx from the country that had intensified in the post-war period in Spain and across Europe. Unfortunately for the ruling party, these recalcitrant Falangists had a social conscience (Del Molino, 2016). Throughout the 50s, José Antonio Nieves Conde's films are rooted in a Falangist disconformity with the socio-political ideology of the Francoist regime, which they believed had betrayed the social spirit of the national syndicalist movement's founding father, José Antonio Primo de Rivera. This old guard clung on to an 'idea of Falangism which was social, renewing and to some degree left-wing ... which between 1945 and 1955 energetically aired ideas and opinions that often bordered on the limits of official censorship' (Mainer, 1972). Nieves Conde aimed to bring a new aesthetic to Spanish cinema by bringing it into touch with everyday reality. But beyond that, his films were saturated with clear ideological intentions and an advocacy of the 'National Catholic Movement' and the drift towards rapprochement with the

7 To name among others: That Happy Couple (Esa pareja feliz, 1951), co-directed by Juan Antonio Bardem and Luis García Berlanga, and The Last Horse (El último caballo, 1950) by Edgar Neville. 
Western powers (Marcos, 2015). Furrows is a work of moral censure (Gubern, 2007). In fact, the message is drilled home in the very first frames of the film projecting Montes' original text:

The attractions of the city reach even the most distant villages, inviting the labourers in the fields to desert their lands with promises of easy riches. Beguiled by metropolitan temptations they are ill prepared to resist or control, these country folk, who have lost the [simplicity of] the countryside and have not learned [the complexities of] civilised life, are rootless trees, shards among the slums which life destroys and corrupts. This constitutes the most painful problem of our times ... This is not symbolic, but unfortunately an all too frequent event today.

Table 3. Discourse variables for cinematic analysis, Furrows

\begin{tabular}{|c|c|}
\hline \multirow[t]{2}{*}{ Furrows } & VISUAL AND SOUND ASPECTS \\
\hline & $\begin{array}{l}\text { Narrative space: The film reflects the growth of Madrid in the } 1950 \text { s, which saw a housing } \\
\text { development belt around the city to accommodate those working in the outskirts. } \\
\text { Locations: The main locations for the film were the then deprived Madrid districts of Lavapiés, } \\
\text { Ventas, Cuatro Caminos, and other deprived areas in the margins of the city. } \\
\text { Historical time: } 1950 \mathrm{~s} \text {. } \\
\text { Image: Black and white. } \\
\text { Photography: In terms of its treatment of city life, it has certain echoes of American film noir, } \\
\text { focusing on those on the margins of society. } \\
\text { Dialogues: Featured in this paper. } \\
\text { BSO Extradiegetic: Classical setting. Diegetic: City ambient sound: traffic, railway station, subway. } \\
\text { Artists who perform popular songs from southern Spain perform at the neighborhood party held at } \\
\text { the La Latina theatre. }\end{array}$ \\
\hline & NARRATIVE AND PLOT ASPECTS \\
\hline & $\begin{array}{l}\text { Film genre: Melodrama and neorealism (albeit muted by Francoist restrictions). } \\
\text { Character: Manuel, the father, finds work at the foundry, but is unable to keep up with the demands } \\
\text { of the job, for which his previous life in the fields has not prepared him. Under the influence of } \\
\text { his cousin Pili, Pepe, the eldest of the three children, is drawn into the shady world of the black } \\
\text { market, and into the orbit of Pilis boyfriend, the gang leader who is known as El Mellao. Manolo, } \\
\text { the youngest son, finds work as a delivery boy, but later must be taken in by a family of puppeteers. } \\
\text { And lastly, Tonia, the younger sister, begins working as a maid, but it soon transpires that she has } \\
\text { been entrapped for the designs of El Chamberlain, 'the boss', owner of the neighbourhood bar and } \\
\text { kingpin at the centre of all criminal activity on his patch. } \\
\text { Summary plot and context: Furrows follows the fortunes of a poor family from the country who } \\
\text { leave their village in search of a better life in post-war Madrid. In this regard it is a familiar story - an } \\
\text { attempt to escape from rural poverty to a brighter prospect offered by capitalist industrialisation, } \\
\text { which turns out to be implacable, soul-destroying, and full of insurmountable hurdles. } \\
\text { Rural elements in story: Furrows driving home the message that the city corrupts; in the struggle } \\
\text { to survive, there is little choice but to prostitute oneself and engage in delinquency. The situation, the } \\
\text { film argues, might be bad, but the solution does not lie in displacements of whole rural populations. }\end{array}$ \\
\hline & AXIOLOGICAL ASPECTS \\
\hline & $\begin{array}{l}\text { Specific: The catalogue of social ills, both implicitly evoked and explicitly depicted in Furrows, } \\
\text { includes: the precariousness of housing, evinced in the scenes set in the communal patio; the queues } \\
\text { at the employment office and the obstacles the protagonists must overcome to find work; the world of } \\
\text { scamming, the black market, unlicensed peddling and semi-organised crime, with its promise of easy } \\
\text { money for those with time on their hands; the hunger and misery of the destitute waiting for food at } \\
\text { the gates of the barracks, accentuated by the shots of buildings in ruins; the unremitting backdrop of } \\
\text { dirty, ragged children playing in the street; and the sexual exploitation of women (Marcos, 2015, p. } \\
\text { 209). Family, religion, honour, and integrity. } \\
\text { General: Individual and group identity, scarcity of socioeconomic-work opportunities, erosion of a } \\
\text { way of life and sense of loss. }\end{array}$ \\
\hline
\end{tabular}

Own elaboration

A film that focuses on the phenomenon of the 'chabolas' or unregulated self-built slum dwellings ${ }^{8}$ is Near the City (Cerca de la ciudad, 1952) by Luis Lucia, the premise of which is that the city is a hostile

8 The notion of 'Greater Madrid' began to take shape in 1950 when municipalities such as Aravaca, Barajas, Canillas, los Carabancheles, Hortaleza, Vallecas, Vicálvaro and so on were absorbed into the city. The previous Madrid suburbs beyond the Paseo de Ronda (Tetuán, 
environment for immigrants from outlying rural areas, and it is better not to set foot there. In the film Furrows, traditional Spanish values (family, religion, honour, and integrity), which had formed the ideological bedrock of Falangism (which fetishized agrarian society), were eroded by the city (Silvestre Rodríguez and Serrano Asenjo, 2012). This can be seen in the official poster, the design of which consists of two parts. In the bottom half, we can see the Pérez family, backs to the viewer, walking over a neatly ploughed field towards the city in the distance, carrying with them all their possessions. In the top half is the representation of a high-rise city, over which presides, like a looming King Kong or Godzilla, a gangster-like figure in a suit, his face shaded by a trilby, stretching his right hand towards the unsuspecting labourers, who are about to be irreversibly engulfed by the city, swallowed by the menacing giant before them, and - should they survive - spat back to the countryside from which they came (Sojo Gil, 2011). The poster caused the director a lot of problems, as it gave explicit shape to what until then had been invisible.

The moral custodians of the time launched a virulent backlash against the film. The church, censors, and most conservative elements within the Francoist regime were alarmed by the potentially subversive threat of the film's premise, suggesting that economic inertia creates the conditions for the flourishing of fraudsters, black marketers, kept women, and women who smoke, frequent bars, and live with men, or have sexual relations with men, outside the bonds of matrimony. Despite the revolutionary focus of the film, certain foregrounded themes and aspects reflect the era, and sharply contrast with the far more conservative 'rural' values. A reference to religious practices as antiquated is given to the eldest child, Pepe, when he returns home to find the family reciting the rosary, saying, 'I've told you before, these things are fine for the village'.

\subsection{From 1960 to 1981. Intensification of migration from the country to the town}

On 21 July 1959, the stabilisation plan was approved, which gave way to the well-known 'Spanish Miracle', making way for the technocrats who liberalised the economy by replacing military uniforms with suits and ties, and Millán Astray with López Rodó (Izquierdo Vallina, 2016, p. 16). A situation that split the Spanish countryside in two. It was what del Molino (2016, p. 61) calls 'the great trauma', which meant that between 1950 and 1960, three Spanish provinces (Madrid, Barcelona, and Vizcaya) registered the highest population growth rates in their history, like many provincial capitals, while the countryside emptied and 14 provinces were plunged into a sociodemographic decline, from which they still suffer the consequences. The Spanish miracle was only for the cities linked to industrialisation and the development of 'sun and sand' tourism.

\subsection{1. 'Sunburn' (1967): eternal dichotomies between rural and tourist areas, immigration and emigration, development, and underdevelopment}

This 1967 film, directed by Josep Maria Forn, won the 'Espiga de Plata' ('Silver Ear' - ear of corn, wheat etc) the following year at the $13^{\text {th }}$ Valladolid International Cinema Week, while the actor playing the leading role won the Silver Fotogramas award in 1967, and the Cinema Writers Circle awarded it the prize for Best Screenplay and Best Actress.

The film met with various problems from the board of censors. The most significant of these, according to Forn, was the scripting of expressions in Catalan, something which had not been attempted before under the Francoist dictatorship. Another was the scene in which the protagonist, who has established himself in Lloret del Mar in advance of his family, beds a tourist. Although careful camera angles ensure the woman's naked body is not seen, the censors nevertheless decided that 'the audience's mind gets to work and knows she is naked' (Agencia EFE, 2009).

According to the director himself, inspiration from the film came to him when he was taking a walk in the coastal resort of Roses and saw piles and piles of bricks. Aside from the visual impact of the urban transformation of the Costa Brava which the bricks represented, he was struck by a group of labourers working under a burning sun (Quintana, 2017). The dichotomies referenced in the heading for this section are brought into play by three archetypal figures which were conspicuous during the so-called 'Spanish Miracle' of the Franco dictatorship: the immigrant, the tourist, and the resident. In one scene, during

Prosperidad, Guindalera, Vallecas, etc.) had a network of roads, sewerage, and wáter supply, albeit not always as far as individual houses (Otero Carvajal, 2010). 
a work-break, the main character, José, picks up a guitar and begins to strum a tune from his land in the south. As he sings, the film intersperses a silent flashback sequence showing Josés desperation to maintain his family as the landowner picks out the lucky few to work in the fields. The scenes set in the village and on the train as the family travels to Catalonia contrast the entrenched traditions which constrict life in the country with the freedoms enjoyed by the tourists through their affluence and relaxed attitudes.

Table 4. Discourse variables for cinematic analysis, La piel quemada (Sunburn)

\begin{tabular}{|c|c|}
\hline Sunburn & VISUAL AND SOUND ASPECTS \\
\hline & $\begin{array}{l}\text { Narrative space: Costa Brava. } \\
\text { Locations: Lloret de Mar (Girona-Catalonia) and Guadix (Granada-Andalusia). } \\
\text { Historical time: The action all takes place within 24-hour period, within which the director con- } \\
\text { jures a portrait of } 60 \text { s Spain. } \\
\text { Image: Black and white. } \\
\text { Photography: The images contrast the poverty and marginality of the countryside with the develop- } \\
\text { mentalism of the coast in an almost documentary representation. } \\
\text { Dialogues: Featured in this paper. } \\
\text { BSO Diegetic: In the tavern scene, in which José is celebrating the imminent arrival of his family } \\
\text { from Guadix (Granada) with some workmates, the group begins to sing and dance to Josés guitar. } \\
\text { And begins to strum a tune from his land in the south. }\end{array}$ \\
\hline & NARRATIVE AND PLOT ASPECTS \\
\hline & $\begin{array}{l}\text { Film genre: Social drama and neoralism. } \\
\text { Character: José (the main character) his wife, Juana, their children, and his brother - and con- } \\
\text { struction co-workers. The comparison between the tourists and the southern 'Spanish male' is fore- } \\
\text { grounded throughout the film. The northern Europeans, in their trunks and bikinis, are otherworld- } \\
\text { ly - fair haired, statuesque and toned. The Spanish residents are divided into the Catalan bourgeoisie } \\
\text { (superior and contemptuous) and the migrant workforce from the south (impoverished and gauche). } \\
\text { Summary plot and context: The circumstances forcing the family to make the trek - journeying } \\
\text { from rural Andalusia to Lloret del Mar on the Costa Brava to join the head of the family, who has } \\
\text { found work as a labourer on a building project for the burgeoning tourist industry - are given in a } \\
\text { series of flashbacks, which also make a contrast between the two ways of life. } \\
\text { Rural elements in story: The feature film centres on the personal stories of internal rural migrants } \\
\text { making their way to Catalonia in the hope of finding 'paradise' (in an almost literal sense given the } \\
\text { lack of freedom in their place of origin). The issues had a contemporary resonance, analysing the } \\
\text { impact of rural depopulation, and questioning the Fordist model of 'sun and sand' tourism and its } \\
\text { territorial consequences. }\end{array}$ \\
\hline & AXIOLOGICAL ASPECTS \\
\hline & $\begin{array}{l}\text { Specific: The explicit - and at times implicit and symbolic - depiction of the exploitation suffered } \\
\text { by the family, both as agricultural labourers under the regime of the local bosses in their home village, } \\
\text { and as migrant workers by the part the Catalan bourgeoisie on the building site. Other issues raised } \\
\text { by the film include the superior attitude of the well-off Catalonia residents towards the newcomers } \\
\text { from other parts of Spain, the antagonism towards the Catalan language as a symbol of identity and } \\
\text { cultural manifestation, sexual repression, desire, and the struggle to make a better life for oneself. } \\
\text { General: Individual and group identity. Scarcity of socioeconomic-work opportunities. Erosion of } \\
\text { a way of life and sense of loss. }\end{array}$ \\
\hline
\end{tabular}

Own elaboration

This conflict comes to a head in the tavern scene, in which José is celebrating the imminent arrival of his family from Guadix (Granada) with some workmates. The group begins to sing and dance to José's guitar, and as the volume increases, they are reprimanded by a local demanding in Catalan that they stop and receiving the response that they cannot understand him. The confrontation inevitably escalates, and the migrants are subjected to hatespeech: 'charnegos', 'mursianos' (perjoratives directed at economic migrants by Catalans), and 'Go back home'. When the instigators depart, Andrés, José's workmate, addresses the waiter and owner of the bar:

Antonio, you know me. You're Catalan and you know what I think. That's why don't like it when some self-important prats come here and call me 'charnego'.

To which Antonio replies: 
Yeah, I know. You know what we call them round here? 'Gamarusos'. ${ }^{9}$ Because they think that just because they've got a bit of cash to flash they own the world.

Andrés continues:

It isn't right, you know. With all their talk about 'If only Catalonia, if only...'

At this point José puts an arm around his neck and cuts him short:

Leave it, don't keep on about it, just leave off Catalans and all that crap. It's bad enough having to find some way to feed yourself like we do. And I'd rather have those arrogant berks who at least do a week's work than the ones we've got where I come from. All prim and proper and boy can they talk, but they won't lift a finger. You're dying of hunger and they say, 'Peace, my friend'.

This is undoubtedly a clear declaration of intent by the lead character. A similar scene occurs on the arrival of José wife, Juana, with their children and his brother. As they get their bearings at the Lloret del Mar bus station, some residents sitting at a restaurant terrace across the road look on disapprovingly and exchange the remarks below (originally in the Catalan vernacular):

Look the population of Lloret has just gone up again. There's no room for any more And these are the sort that stay because they're grasping.

And their children turn out more pro-Catalonia than you (the waiter interjects).

No way. Nobody's more pro-Catalonia than me.

They're like snails, carrying all they own on their backs (says another person at the table).

\subsection{2. 'Tourism is a great invention' (1967): applying the principles of tourism to the rural sphere as a development strategy for subsistence}

El Turismo es un gran invento is typical of the 'españolada' supra-genre - films, including musical and broad comedies, based on clichéd portraits of national stereotypes. Directed by Pedro Lazaga and released in 1967, it offers a far less critical or nuanced view of the Spanish miracle than La piel quemada. Instead, it represents a direct and explicit reflection of the prevailing attitudes to the role of tourism in Spain in the 60s (Gómez Alonso, 2006). Despite its marked success at the box-office (Crumbaugh, 2007, p. 147), it has been accused by Peris Llorca (2007, p. 363) of being 'a work of Francoist propaganda'. What is certain is that it has mainstream appeal, and that its plot shows the determined attempt of the political authorities in a small town to capitalise on the growing tourism industry and so improve the economy and the country's image abroad.

The inexhaustibly upbeat chorus chirrups in the jaunty tune of a song in film say 'tourism is an exciting way to learn ... Forget about your problems!' A voice-over then takes up the theme: 'Tourism, tourism, tourism! A magical word which today is on everybody's lips, but which yesterday, despite being in the dictionary, nobody knew what it meant.'

The prologue essentially takes the form of a public information newsreel, and like its real-life counterpart, its purpose is effectively to crow an uncritical paean to the regime and its development project that is transforming the physiognomy of the Spanish coastline. The film then switches to a small rural town in the outskirts of Moncayo which is seeing its youth inexorably ebbing away to find work in Zaragoza. The comical and excitable mayor, Benito Requejo, played by Paco Martínez Soria, describes the alarming situation in the following terms: 'We are forgotten, and what's worse, we're left behind. What we must do is change everything. Get up to date and build the Costa de Valdemorillo here.'

The fiction of the personal experience of the mayor and the municipal secretary challenges the audience in a kind of national self-reference. That is to say, the activity of being a tourist acquires a symbolic dimension of collective self-affirmation which provides the key to interpret the significance of the transformations taking place and the possibilities opening to all inhabitants of the country (Crumbaugh, 2007).

In another scene, for example, the mayor gives his young niece a present of a bikini, which she looks at in wonder as an item that is still alien to the rural life that she knows. The resolution finally arrives when the townspeople read the declarations of the minister for Information and Tourism in the newspaper: 'Let no corner of Spain fail to become a tourist zone for the whole world to admire'. In the end the political authorities contrive to rescue the situation and satisfy the modernising desires by conferring a

9 Catalan: boorish and uncouth. 
Parador Nacional (state-sponsored hotel) upon the town. The patriarchal and repressive nature of the Franco regime is thus underlined, something which some authors consider to be the cause of a psychic negotiation involving a 'Pact of forgetting' during the transition (Vilarós, 2002, p. 198).

Table 5. Discourse variables for cinematic analysis, Tourism is a great invention

\begin{tabular}{|c|c|}
\hline $\begin{array}{l}\text { Tourism is a great } \\
\text { invention }\end{array}$ & VISUAL AND SOUND ASPECTS \\
\hline & $\begin{array}{l}\text { Narrative space: Valdemorillo, a small rural town (fictional) in the outskirts of Moncayo (Zarago- } \\
\text { za-Aragón) and the Costa del Sol. } \\
\text { Locations: Valdemoro (Madrid) and Torremolinos (Málaga). } \\
\text { Historical time: 1960s. } \\
\text { Image: Colour. } \\
\text { Photography: The harshness of the rural landscape of ochre fields and stone houses contrasts with } \\
\text { the brightness of the coastline, its hotels, and beaches. } \\
\text { Dialogues: Featured in this paper. } \\
\text { BSO Extradiegetic: The film opens with shots of crowded beaches, parasols, hotels, and apartment } \\
\text { buildings to the jaunty tune of a song titled I like holidaying abroad in a sub-Sesame Street style. } \\
\text { Diegetic: In the opening celebrations of the Parador Nacional (a state-sponsored hotel) there is no } \\
\text { lack of local folklore as a metaphor for the necessary coexistence between traditional local cultural } \\
\text { values, heritage resources, and their tourist commercialisation. }\end{array}$ \\
\hline & NARRATIVE AND PLOT ASPECTS \\
\hline & $\begin{array}{l}\text { Film genre: Broad comedies. } \\
\text { Character: Benito Requejo is the mayor and Basilio is his secretary. The metatouristic component } \\
\text { of the cinematic discourse considers tourism as a 'representation', the 'veracity' of which must be } \\
\text { corroborated by the two lead characters through a trip to Torremolinos on the Costa del Sol. } \\
\text { Summary plot and context: After a vacation to a seaside resort, a Spanish mayor attempts to modify } \\
\text { his small rural town for tourists to make money. } \\
\text { Rural elements in story: The film is an allegory of the dichotomy of the two Spains, but rather } \\
\text { than political or ideological divisions, it tackles socio-economic and geographical schisms - between } \\
\text { coastal resorts during transformation, opening-up and development thanks to the injection of cash } \\
\text { from abroad, and the traditionalist rural backwaters which want to climb aboard the gravy train. The } \\
\text { underlying physical and cultural deprivation plaguing the countryside is conveniently toned down } \\
\text { and aestheticized. }\end{array}$ \\
\hline & AXIOLOGICAL ASPECTS \\
\hline & $\begin{array}{l}\text { Specific: The film then switches to a small rural town in the outskirts of Moncayo which is seeing } \\
\text { its youth inexorably ebbing away to find work in Zaragoza. The political power uses tourism as the } \\
\text { factor that guarantees social modernisation and economic progress in rural areas, preserving identity } \\
\text { traits. Deployment of rural stereotypes and tropes. } \\
\text { General: Depopulation and ageing, individual and group identity, lack of services and public invest- } \\
\text { ment, scarcity of socioeconomic-work opportunities and erosion of a way of life and sense of loss. }\end{array}$ \\
\hline
\end{tabular}

Own elaboration

\subsection{From 1981 to the present}

In this period the tendency to rural depopulation has deepened, albeit at a more moderate and decelerated rate, although unlike the previous period, it has been affected by aging and low population replacement rates (births). To these effects can be added those of the economic crisis and the increase in unemployment, which have likely contributed to a reduction in migration over medium to long distances, and a policy of redistribution, deriving from an increase in decentralisation, along with rising prices in the urban property market and a reduction in the availability of rented accommodation (Silvestre, 2010). These factors have contributed to changes in the directionality of migration, facilitated by return migration, suburbanisation, and changes in the profile of the migrant in terms of a higher level of education and a greater sensitivity to the factors contributing to the quality of life. This in turn has given rise to the phenomenon of counter-urbanisation, which became established in Spain in the second half of the 1980s and which became institutionalised with the application for, and development of, the LEADER Community Initiative. Active recovery programmes began to appear under the auspices of sectorial and territorial perspectives, such as Abraza La Tierra (Cling to the Earth), which over time began to diversify and spread around the country, in response to solid proactive and integrative policies responding to the challenges 
of a changing population, as mandated by the EU (Hortelano Mínguez, 2008, p. 84). Nevertheless, such measures are not in themselves sufficient. There is a need for services, multilevel governance, and strategic investment and action (in the medium and long term). Likewise, a comprehensive and integrated vision, where all stakeholders participate in providing new solutions to old problems, from meeting the real needs of each territory and geographical context, to overcoming the old ways of doing politics in favour of a more comprehensive approach (Esparcia, Martínez-Puche and Querol, 2020).

\subsection{1. 'Flowers from another world' (1999): restoring the female population and masculinity in rural Spain against a backdrop of globalised migration}

This film directed by Icíar Bollaín, who also shares screenwriting credits with Julio Llamazares, throws up several points of interest. First, it is the only one of the five selected here directed by a woman, and hence it represents a different focus on a phenomenon which has thus far been treated from a predominantly male perspective. ${ }^{10}$

Nevertheless, although her films tell stories about women, according to Scholz (2005), the director does not wish her films to be interpreted as 'feminist cinema'. In the words of Fernández Santos (1996), Bollaín is 'a genuine film-maker, who makes films that are uncomplicated but not simplistic, easy to watch, but difficult to see into'. Her dramatisation, filmed with a kind of documentary realism, is characterised by a formal simplicity and a stripped-down aesthetic, so as to present scenes which 'look almost as if they filmed from everyday life' (Leinen, 2009, p. 92). Flowers from another world was nominated for best screenplay and revelation actor at the Goya awards and award for best film at the Cannes Critics' Week in 1999.

The tale, as the director recounts (Leinen, 2009), took its inspiration from two distinct but connected real-life events. The first of these was the so-called 'Caravanas de mujeres' (caravans of women) and the singles parties organised by various territories to boost the population, thus emulating the cinematic imaginary of the popular 1951 western Westward the Women. The original, or at least the one which captured a great deal of media attention, was organised in the municipal district of Plan in 1985 (Marín, 1985), and was successful in its aims, despite today being criticised for a perceived 'commodification' of women. The second was the plight of immigrant women of various nationalities who took Spanish husbands to legalise their undocumented status and create a better future for themselves in an unfamiliar and not always welcoming environment. This role is embodied in the character of Patricia, from the Dominican Republic, an honest and self-sacrificing housewife and mother of a young son and daughter who she wants to bring to Spain. She is opposed in this enterprise by Gregoria, her widowed mother-in-law-to-be and stoutly intolerant matriarch, but ultimately wins her over, along with the love of a 'good man' in Damián.

Villacadima, on the outskirts of Santa Eulaia (fictitious village), is a completely abandoned ghost village whose crumbling houses serve as the backdrop to the scene in which Alfonso takes Marirrosi for a walk. Marirrosi is a nurse with her own income from the Basque Country, and mother of a teenage boy. As Alfonso acts as an impromptu guide, she admits that 'so much space and so much silence is scary', to which he replies, 'it's scary because it's dead'.That, says Marirrosi, is also how she feels in the town of Santa Eulalia, while Alfonso asserts that it is where he feels most at home, adding: 'I don't think I would be capable of returning to a city'. This gap, quite apart from the physical and emotional distance, is the reason why this romance is ultimately unable to overcome the obstacles in its path. Marirrosi is not prepared to swap her anodyne and solitary life in Bilbao for the country, Alfonso, for his part, is unable to tear himself away from his roots and his beloved greenhouse.

The title of the film itself - Flowers from Another World - encapsulates an apt metaphor for those who would set down roots in a new land. This is foregrounded in the dialogue between Alfonso and Marirrosi on the topic of growing exotic orchids. She asks, 'Do you think they'll grow here?' to which he replies as he kisses her tenderly: 'With care, everything grows'. However, the town's womenfolk meet the newcomers with undisguised hostility, and give full vent to prejudice:

We'll see how long that one lasts here (...) they're all looking for the same thing (...). Papers and money, and when they've got them, they're off. (...) That one with Carmelo was here this morning.

10 Only three women had previously directed films widely recognised as 'rural': Margarita Alexandre (La gata (The Cat), 1956), Ana Mariscal (El camino (The path), 1963) and Pilar Miró (The Crime of Cuenca (El crimen de Cuenca), 1980). 
What must the house be like! Let's hear it, how did her mother bring her up? To be with men, for sure. I don't want to see that girl round here again!

The menfolk, for their part display a fossilised masculinity which objectifies women as purely sexual beings at the service of procreation. Three old men evaluate the new arrivals as if they were livestock: 'What teeth! What teeth! ... What lips!' Although very different in age, character, and background, Alfonso and the unsophisticated Damián represent a more sensitive, tolerant, and understanding male archetype. By contrast, the middle-aged Carmelo is a violent man who has made his fortune in the construction industry and engages in sexual tourism in the Caribbean. He intends to make a possession of the indomitable, independent, and sensual Milady, whom he has met on one of his trips, without realising that the weaker partner in the one-sided relationship is himself. The bar is the space where people come together and spend their free time away from the daily routine, the men watching the televised football matches and the occasional porn film.

Table 6. Discourse variables for cinematic analysis, Flowers from another world

\begin{tabular}{|c|c|}
\hline $\begin{array}{l}\text { Flowers from } \\
\text { another world }\end{array}$ & VISUAL AND SOUND ASPECTS \\
\hline & $\begin{array}{l}\text { Narrative space: The story takes place in the fictitious village of Santa Eulalia, a bastion of tradi- } \\
\text { tional, Catholic Spain. } \\
\text { Locations: The film was shot on location in the municipalities of Cantalojas, Condemios de Arriba, } \\
\text { Jadraque and Villacadima (Guadalajara). } \\
\text { Historical time: 1990s. } \\
\text { Image: Colour. } \\
\text { Photography: The panoramic outdoor shots of the town, surrounded by a vast plateau in shades of } \\
\text { green and ochre, evoke an unfathomable immensity, depict the agricultural labours, and show the } \\
\text { passage of time in the seasonal changes. They provide a contrast to the closed, hermetic spaces of } \\
\text { the interiors. Some houses such as Damian's, are modest and austere, although homely; others, like } \\
\text { Carmelo's, are more recent, and are ostentatious, but gloomy and impersonal. } \\
\text { Dialogues: Featured in this paper. } \\
\text { BSO: The music, both diegetic and non-diegetic, is also essential for creating moods and narrative } \\
\text { contrasts: the pasodoble performed by the village band to welcome the single women as their bus } \\
\text { arrives; the Caribbean rhythms playing on the car radio, and as the soundtrack when the young Cu- } \\
\text { ban Milady flees rural oppression and Carmelo's possessiveness; the techno of the Valencia disco; and } \\
\text { the evocative instrumental background music as the camera pans over the natural landscapes. There } \\
\text { is a special, symbolic significance to the song 'Contaminate me, mix yourself with me' which the } \\
\text { local band perform at the feast day dance, an invitation to meet the other and so reconfigure the self. }\end{array}$ \\
\hline & NARRATIVE AND PLOT ASPECTS \\
\hline & $\begin{array}{l}\text { Film genre: Social drama. } \\
\text { Character: Patricia, a Dominican, is looking for a home and economic security that her illegal immi- } \\
\text { grant situation does not allow her to achieve in Madrid. Milady, a twenty-year-old Cuban, dreams of } \\
\text { traveling the world. Marirrosi, a woman from Bilbao with a home and a job, lives in complete lone- } \\
\text { liness, a loneliness like the one shared by Alfonso, Damián, and Carmelo, residents of Santa Eulalia, } \\
\text { a town without marriageable women or future. } \\
\text { Summary plot and context: A rural town where single men abound and women are lacking decides } \\
\text { to tackle the problem of depopulation. Thanks to a party organized by the town's bachelors, three } \\
\text { men and three women meet each other, and a bittersweet story of sometimes impossible coexistence } \\
\text { begins. } \\
\text { Rural elements in story: Flowers from another world sheds a light on cultural, socio-economic, and } \\
\text { gender differences between countries, but also the differences between urban and rural Spaniards. }\end{array}$ \\
\hline & AXIOLOGICAL ASPECTS \\
\hline & $\begin{array}{l}\text { Specific: Prejudices and intolerance towards immigrants in rural areas, but the family is presented } \\
\text { as the nucleus of interracial negotiation and potential creation of a more tolerant and multi-ethnic } \\
\text { society. Religion and the most conservative customs, however, continue to appear as the definitive } \\
\text { feature that culminates the inclusion and acceptance of normality. The old dichotomy between city } \\
\text { and country is updated and enriched by the confrontation between national and ethnic stereotypes, } \\
\text { male and female loneliness, emigration, xenophobia, sexism, and family models in rural areas. } \\
\text { General: Depopulation and ageing, individual and group identity, access to education and levels of } \\
\text { education, scarcity of socioeconomic-work opportunities and erosion of a way of life and sense of } \\
\text { loss. }\end{array}$ \\
\hline
\end{tabular}

Own elaboration 


\subsection{2. 'The Stone Violin' (2015): a moribund empty town full of memories}

This film, directed by the writer and journalist Emilio Ruiz Barrachina, is something of a curiosity and quite unique among the films making up this paper. Its eclecticism, form and narrative structure mark it out from the others, although its audio-visual quality and its representation of a valid historical, socioeconomic, geographical, and cultural context more than justify its inclusion.

It specifically focuses on the theme that certain authors have dubbed, in the same vein as the term 'ethnocide', 'demosthanasia', defined as:

A process that both political actions, direct or indirect, and omission of them, is causing the slow and silent disappearance of the population of a territory that migrates and leaves the area without generational relief and with everything that it means, such as disappearance of a millenary culture. It is an induced rather than a violent death. (Cerdá, 2017, p. 35-36; Burillo et al., 2019).

Table 7. Discourse variables for cinematic analysis, The Stone Violin

\begin{tabular}{|c|c|}
\hline The Stone Violin & VISUAL AND SOUND ASPECTS \\
\hline & $\begin{array}{l}\text { Narrative space: Ojos Negros is a village in the fiction without population. } \\
\text { Locations: Buitrago, Braojos, Horcajuelo de la Sierra, La Acebeda and La Hiruela which are in the } \\
\text { Sierra Norte to the north of Madrid. It was supported with a grant from the community association, } \\
\text { Mancomunidad Valle Norte del Lozoya, and the was aided by the participation of the Community of } \\
\text { Madrid's Office for Cultural Promotion. } \\
\text { Historical time: Present but reminiscent of the past and timeless evocation. } \\
\text { Image: Colour and old black and white photos at the beginning of the film. } \\
\text { Photography: The images cut to sweeping panoramas of wild mountains and forested landscapes } \\
\text { covered in snow. These contrast with the severe and inhospitable austerity of houses whose walls } \\
\text { are crumbling into ruins, the shell of a dilapidated car, the wheels long since gone, washed up in an } \\
\text { abandoned courtyard overrun by weeds, and the cold, lonely street of a completely deserted village. } \\
\text { Dialogues: Featured in this paper. } \\
\text { Soundtrack Extradiegetic: The piano accompanies the photographs at the beginning, conveying } \\
\text { melancholy, which increases with the orchestra in the subsequent minutes of general shots of snowy } \\
\text { nature. Diegetic: A group of musicians performs lively popular music, while a deceased is taken for } \\
\text { a walk and greets those present. The music performed by the enigmatic character of the violinist } \\
\text { accompanies the elderly protagonist in the most exciting moments to reinforce the dying loneliness. }\end{array}$ \\
\hline & NARRATIVE AND PLOT ASPECTS \\
\hline & $\begin{array}{l}\text { Film genre: Drama and comedy. } \\
\text { Character: Angel, the main character, talks with the silent and young spectre of his deceased wife. } \\
\text { The violinist, clad in a black gabardine, is another enigmatic presence among the group of allegor- } \\
\text { ical characters some sinister, like the mayor, a sexual predator, others ridiculous and parodic, like } \\
\text { decamped city dwellers playing at being country folk, whose passage is ill-adapted and short-lived } \\
\text { - and the bartender, the tenor, the man in the beret, and the 'Latin Americans'. } \\
\text { Summary plot and context: An emotional story about empty Spain. The last inhabitant of a town } \\
\text { lives with his memories and his dead just now when a strange violinist comes to take him to the } \\
\text { grave. While the most important moments of this place, which will die together with its protagonist, } \\
\text { are coming to life in a story of love, execution, and secrets that will never see the light of day. Bitter } \\
\text { comedy about rural depopulation and its consequences for a society that is forgetting its essence. } \\
\text { Rural elements in story: The concept of the rural does not draw on clichés which identify it as } \\
\text { an atavistic, unsophisticated, and traditionalist space in counterpoint to urban modernity. Nor is it } \\
\text { the bucolic idealisation of some Francoist 'happy Arcadia' safeguarding the patriotic essence of the } \\
\text { nation against the dangers of progress. }\end{array}$ \\
\hline & AXIOLOGICAL ASPECTS \\
\hline & $\begin{array}{l}\text { Specific: Claiming the memory of the uninhabited peoples of empty Spain and denouncing the } \\
\text { irreparable loss of rural spaces and their sociocultural, demographic, and human dimension in a } \\
\text { modern and capitalist society. } \\
\text { General: Depopulation and ageing, individual and group identity, lack of services and public invest- } \\
\text { ment, scarcity of socioeconomic-work opportunities and erosion of a way of life and sense of loss. }\end{array}$ \\
\hline
\end{tabular}

Own elaboration

The film is also quite unlike any other film in the catalogue of 'rural cinema'. To a certain extent, it follows in the line of films that can be classed surrealist or absurdist such as José Luis Cuerda's 1989 
Amanece, que no es poco ('It's sunrise, which is no small thing'), and has the intimate poetic aesthetic of Victor Erice's 1983 El Sur (The South). It has influenced the work of young directors such as Oliver Laxe's 2019 Fire Will Come (O que arde), Carla Simón's 2017 Summer 1993 (Verano 1993) and Marta Lallana's 2018 Ojos Negros (Dark Eyes). The latter two works take a feminine perspective with autobiographical shades, approaching the rural environment through memories of childhood and adolescence respectively.

The film's explicit accusatory tone, its condemnation of the disappearance of the rural world and its intention to kindle reflection on demographic aging and depopulation can be seen not only in the origins of the project ${ }^{11}$ and the fiction it depicts, but also in the news reports about the film on its release. ${ }^{12}$

The prologue is also a homage, a manifesto, and a declaration of love and intentions. Sepia photographs show walled fortresses, churches, manor houses, natural landscapes, and everyday scenes of bygone social gatherings, while a piano plays and the voice of the main character delivers its heartfelt verdict:

The land is fertile; the cemetery sterile. Why force sterility upon us? Thus, have we created a society ruled solely by values which can be given a price. The rural world is in its death throes. The death of a community is much more than that of a handful of people. People are born and then they die. But when a community dies, nothing can be born again. ${ }^{13}$

The story draws liberally on magical realism ${ }^{14}$ to freely combine disparate genres, ranging from episodic comedy via docudrama to existentialist monologue, literally conjuring up the main character's memories of youth and his past life, attended by the silent and mournful spectre of Soledad, his young deceased wife. It is impossible not to find clear literary associations with Juan Rulfo's Pedro Páramo.

In the words of the central character 'they came when it seemed that money sprouted like beans in the garden, as if by spontaneous generation', when people lived in the town and even people from the city visited or emigrants from other countries resided. Times when life flourished. All now left behind.

\section{Discussion of results}

There can be no doubt that both versions of The Cursed Village (1930-1942) reflect a situation which had affected rural Spain since the second half of the nineteenth century. Seasonal variability in the work, poor harvests, precarious living conditions, urban industrialisation, and the constant drain from the countryside to towns were common features throughout Europe. The 1942 version includes an impressive scene, opening the second section, 'Exodus' features a convoy of horse-drawn wagons filing into the square loaded with farming implements and furniture. One of those remaining asks: 'And are all these people leaving?' and receives the reply: 'All of them. Only the old folk like you and me are staying'. 'And where are they going?' 'Wherever they can. Some to Salamanca, others to the Lands of Aragón'. When Juan also leaves for town, 'Tío' Lucas buys his land, commenting: 'Once you settle in town, you'll forget the village, like everybody else. This is a graveyard, Juan'. It encapsulates the sense of uprootedness and being set adrift implicit in 'the rural versus the urban', a sentiment most keenly felt by the young people when it came to leave, as shall be seen in the other films, and something which has persisted to the present day. ${ }^{15}$

Furrows sets the traditional social and religious values, represented by rural life, the family, paternal authority, religion, and order, against the city, which represents libertinism, mass disorganisation, selfish individualism, easy money, capitalism, and the alien. The film is a denunciation of the rural exodus to the city, something the government first tried to halt, and then, in the following decade, tried to encourage (Marcos, 2015). The film certainly gives palpable treatment to the cultural, economic, and social gap

11 The initiative for the film originated in the community association, Mancomunidad de la Sierra Norte de Madrid which comprises 42 small municipalities in De la Cal (2015).

12 'It proclaims the necessity for continuity in rural communities across Spain through belief in a future fashioned out of projects which protect its diversity of heritage and involves its inhabitants', in News (29 May 2016) El violin de piedra was premiered on Friday. El Correo de España. Retrieved from https://tinyurl.com/y5yfcxrk

13 The film director asserted that the root cause of the rural exodus is pre-eminently 'an economic problem', in J.B. (8 July 2015) El violin de piedra, a communal labour in the Sierra de Madrid. La Nueva España.es. Retrieved from https://tinyurl.com/y4ejw75v

14 After the prologue, and before the film proper, an intertitle offers the following text: 'At the moment of death, memories pertain to feelings and not necessarily to reality'.

15 In the scene just before the start of Section II (Exodus), following the loss of the harvest to a storm, Acacia tells Juan, 'It doesn't matter that we've lost it. We're young, strong. We can start all over. Not here, but down on the plain. Or in the town, Juan. In the town.,' to which Juan replies, 'Yes, Acacia, you're right, that's what I'll do' 
between town and country, and it must be said that the new arrivals from the country behave extremely awkwardly in the face of the dangers and temptations of the city.

The poor performance of the Spanish economy in general, and that of Madrid in particular, did not put a brake on the influx to the city. Some sources put the number of migrants to Madrid during the 1940 s at 272,125 , the equivalent of $18.31 \%$ of the population, a pattern which continued in the following decade (Silvestre Rodríguez and Serrano Asenjo, 2012). The main driver of this migration was the worsening conditions of life in the country, as the area of cultivated land diminished, foreign exchange declined, and hunger and misery took hold.

A diachronic analysis of the Spanish films in the social and neorealism tradition would regard the film La piel quemada ('Sunburn') as a successor to The Cursed Village (1930) and Furrows (1951). Set in Lloret del Mar against a backdrop of the opening of Francoist Spain to tourism, it is set in the Andalusian exodus to Catalonia when the first wave of tourists hits the Costa Brava. In Forn's own words:

The 50s saw the rise in migration because of people going hungry, because of absolute misery, because it wasn't possible for people to live in Andalusia, or Extremadura, or Murcia, and so some ended up in Catalonia while others continued into Europe. I wanted my film to reflect all this migratory movement, which continued right up until the 70s. So I asked myself, what was that phenomenon in which people emigrated because they were going hungry, what was it that emigration caused this situation? And the explanation was none other than the agrarian latifundium system in the south, and that people finding themselves in Catalonia were trying to integrate in a place which was very different and had a very different culture. The influx of migrant workers coincided with the arrival of another influx coming for quite the opposite reasons - Europeans benefitting from postwar economic expansion who were beginning to get a taste for the Spanish sun and beaches (Moyano, 2016, p. 31).

In the film Tourism is a great invention, the two start out as diegetic spectators and avid apprentices Requejo ${ }^{16}$ constantly says to his secretary 'Goodness! Write that down! Write that down!' - and impressed by the bikini-clad foreign tourists and the hotel facilities, they return to their town converted into active agents of tourism development. Their plans occasion frustrating mismatches between the aspiration for progress and day to day rural life, such as the reluctance of the womenfolk, who see the possible arrival of attractive women from abroad as a threat. This situation foreshadows the theme considered below vis-à-vis the sociocultural interaction with foreign women, albeit as a result not of tourism but rather immigration, in the film Flowers from another world.

Today, this flow is reversed as rural tourism in the interior of the country is being promoted ${ }^{17}$ as an alternative leisure activity which can diversify and complement the standard beach-based holiday model, while at the same time providing business initiatives for combatting increasing depopulation. ${ }^{18}$

The film Flowers from another world belongs to a long list of Spanish films from the 70s and 80s which revisited the theme of post-liberalisation. It takes the perspective of social drama and class conflict and shows what happens when the 'industrial progress promised by the social conscience, hits a crisis point' (González Requena, 1988, p. 24). Bollain directs the focus onto the theme of depopulation, the consequences of the phenomenon of migration, and coming to terms with all that is foreign. For Robertson (2002), the film can be classed as an innovative cinematic introduction to 'glocalization', by which Spain transformed from being a sending country to a receiving country. ${ }^{19}$

For his part, Ballesteros claims that the film 'exposes the prejudice and intolerance towards immigrants in the rural environment, but the family is presented as the centre of interracial negotiation and the possible creation of a more tolerant and multi-ethnic society' (2016, p. 257). All to the good, but religious beliefs and conservative traditions remain the yardstick for inclusion and acceptance when, towards the end, Patricia's daughter Janay celebrates her first communion. The old dichotomy of town and country is

16 'Requejo' is an archaism meaning 'terrain, territory, place, location'.

17 García Marcos, E. (18 Octuber 2019). A group of experts propose 10 measures to halt rural depopulation Hosteltur. Retrieved from https:// tinyurl.com/y6od5j32

18 Technology for preventing rural depopulation and promoting tourism (18 April 2019), Hosteltur. Retrieved from https://tinyurl.com/ yycrrx8t

19 The arrival, in this case unexpected and by chance, of African immigrants in a town at risk of depopulation also forms the plot of the comedy A Remarkable Tale (Lo nunca visto, Marina Seresesky, 2019). 
brought up to date and enriched by the themes of the confrontation between national and ethnic stereotypes, male and female solitude, xenophobia, sexism, and family models in the rural sphere.

In the representation of The Stone Violin, the concept of the rural does not draw on clichés which identify it as an atavistic, unsophisticated, and traditionalist space in counterpoint to urban modernity. Nor is it the bucolic idealisation of some Francoist 'happy Arcadia' safeguarding the patriotic essence of the nation against the dangers of progress. The recovery, or rescue, of these territories is the responsibility of the public administration and a recognition of the irreparable loss from a sociological and anthropological point of view. The nostalgia evoked by the memories of the last inhabitant of a village Ojos Negros, in the fiction depicted in the film, an elderly man called Ángel - a name replete with presentiment - becomes a symbol and common thread in the chronicle of a death foretold of a man and a community.

\section{Conclusions}

The process of migration from the countryside to the city began in the second half of the eighteenth century and gathered force in subsequent centuries. Camarero (2020, p. 51), citing Fermín Caballero, whose work Promotion of the Rural Population was published in 1864, draws attention to the uneasiness transmitted by this and other authors of the time with regard to the vast depopulated wastelands across Spain. He also quotes Costa (1911), for whom the best panacea to prevent depopulation were the reservoirs, 'because the mountains are condemned to depopulation, as the mountain population has to move onto the plains, and it is necessary that this happens, and it cannot happen while the plains are not watered' (Costa Martínez, 1911, p. 61). Franco's National Plans for Agrarian Colonisation drew heavily on the ideas espoused by Caballero and Costa, aiming to incorporate the expansion of irrigation, and to establish a population to bring territory perceived as wasteland under control. Despite the continuing rural exodus, however, the issue of depopulation would remain a secondary concern until the second half of the twentieth century.

The harsh conditions of the farming areas, restricted by the latifundium system, and the processes of industrialisation and urbanisation inevitably led to a population shift from country to town. This is underlined in the two versions of The Cursed Village (1930 and 1942). Nor did the situation of the shattered Spanish economy in general prevent the drift of migrants to the towns in the post-war period. This was because the quality of life in the country worsened considerably due to the reduction of land under cultivation. This, added to the decline in international trade, meant that there was widespread lack of food and suffering. Conditions for agricultural labourers were not only intolerably hard, but also precarious: "with inadequate daily rates ... when an especially bad year arrives, or when with every new season there are fewer workdays available, then no other option remains but to find another route. And the only route remaining is to leave' (Silvestre Rodríguez and Serrano Asenjo, 2012, p. 107).

What was to come was hardly any better. The stabilization plan (1959) involved industrialisation and the development of tourism, but also led to the intensification of agriculture, the establishment of patents (plants and animals), irrigation, and the Minimum Wages Act, which accelerated the mechanisation of farming to avoid paying decent daily rates (García-Delgado, 2009) and which led to the rural exodus and uprooting depicted in Furrows.

The migratory flows began to impact capital in the Francoist economy in 1957, at which point the regime felt compelled to liberate internal and external population movements, the best cinematic example of which is the 1971 Pedro Lazaga release ¡Vente a Alemania Pepe! (Come to Germany, Joe!). With respect to internal migrations, these were from the poorest regions - Andalusia, Extremadura, and Castilla La Mancha - to mostly Madrid and Barcelona. It is calculated that between 1962 and 1973 nearly four million people changed their place of residence. One area which received more people than most was Catalonia, in particular the Barcelona metropolitan zone, followed by the tourist areas because of the growing demand in the service and construction sectors. The relationship between the myth of tourism promoted by the Francoist regime and the social reality resulting from internal migration to the coastal areas is a key factor in understanding the context and story of La piel quemada (1967). It is, in fact, the only film of that decade to directly tackle the contradictions generated by tourism and the transformations caused by migration in Spain (Quintana, 2017). In total contrast is the film El turismo es un gran invento (1968), in which the ingenuous awestruck villagers are rewarded by the dictatorship with a state-sponsored luxury hotel. 
Neither democracy nor the aimed-for agrarian reforms managed to reduce the rural exodus. Indeed, there has even arisen a process which has been denominated 'perverse development' by which agricultural income is targeted at youth training programmes in cities, but those taking part never return for lack of opportunities (García-Delgado, 2009, p. 26), or because of the suffocating prospects of the rural world. It is in this context that a new wave of intercultural migration emerged, whereby a country which was formerly marked by the experience of emigration became one which had to adapt to the new experience of immigration. The theme of the expectations of individual or family 'repopulation', in which immigrants, 'neorurals' and the local population coexist, are explored in Flowers from Another World (1999). However, the process requires a period of adaptation and cultural metabolization, which is not always easy, especially if the cultural substrate is different. Migration from the city to the country should not be an end in itself, but rather a means.

Meanwhile, despite subsidies and reverse migration from the city to the countryside, the phenomenon of 'hollowed out Spain' continues unabated. It may be that the neoliberal discourse demanding fiscal responsibility from public services has effectively committed demosthanasia. Spain's Economic and Social Forum noted in its 2018 report that of the 8,131 municipalities in Spain, 73\% have less than 2,000 inhabitants while accounting for $55 \%$ of the area.

The need to face population challenges as a matter of state policy is evident from the evolution of the population of Spain, and of developed countries as a whole, over the last decade, as can be seen in the data published by the Spanish Statistical Office (INE), Eurostat and the World Bank, and is further underlined by the commitment of those Spanish regions which have been most affected by demographic imbalances. For this reason, the VI Conference of Presidents ${ }^{20}$ was held in 2017 (17 January), at which the Commission for the Demographic Challenge was created and charged with establishing a common strategy. In addition, the regions themselves have initiated actions and developed structures, such as the Agenda Valenciana Antidespoblament (AVANT) (Valencia Counter-depopulation Programme), created in 2017 and responsible to the Valencia Regional Government. In 2018, the programme ratified four AVANT university chairs (Jaume I, Valencia, Politécnica de Valencia, and Alicante), and in August 2019 established a general directorate responsible to the presidency of the regional government. One of the programme's first actions was to draft the Valencia Counter-Depopulation Strategic Plan (PLESVANT), coordinated by the University of Valencia. Despite difficulties, 2020 saw the development of various widely agreed measures and actions, in which the public participation of all stakeholders and the contributions of the AVANT interuniversity chairs were particularly noteworthy.

\section{Funding}

Project of the State R\&D\&I Plan of the Ministry of Science and Innovation. Spanish cities in audiovisual fiction. Documentary record and territorial and audiovisual analysis (FACES-50). Reference: 2019/00436/001

\section{References}

Abril, G. (2007). Análisis crítico de los textos visuales. Mirar lo que nos mira. Madrid, España: Síntesis.

Agencia EFE (5 de agosto 2009). La piel quemada, vuelve a la cartelera 43 años después. El Mundo. Retrieved from https://tinyurl.com/y6ptjkbq

Ballesteros, I. (2016). Éxodo rural, migración e inmigración en el cine español. Hispanófila. Vademécum del cine iberoamericano: métodos y teorias, 177, 249-261. https://doi.org/10.1353/hsf.2016.0042

Burillo, M.P., Rubio, P., \& Burillo, F. (2019). Strategies facing the depopulation of the Serrania Celtibérica within the framework of the European cohesion policy 2021-2027. Economía Agraria y Recursos Naturales, 19(1), 83-97. https://doi.org/10.7201/earn.2019.01.05

Camarero, L. (2020). Despoblamiento, baja densidad y brecha rural: un recorrido por una España desigual. Panorama Social, (31), 47-73. Retrieved from https://www.funcas.es/wp-content/uploads/2020/09/ Panorama-Social-31-digital-2.pdf

20 'The Conference of Presidents is the body of highest political level of cooperation between the state and the Regional Governments'. Retrieved from http://www.mptfp.es/en/portal/politica-territorial/autonomica/coop_autonomica/Confer_Presidentes.html 
Capel, H. (1967). Los estudios acerca de las migraciones interiores en España. Revista de Geografía, (1), 7-101.

Castiello, C.H. (2010). Con maletas de cartón: la emigración española en el cine. San Sebastián: Gakoa.

Cerdá, P. (2017). Los últimos. Voces de La Laponia Española. Logroño: Pepitas de calabaza.

Collantes, F., Kerstin, E., \& Prados, L. (2016). In Memoriam: Lennart Schön. Investigaciones de Historia Económica, 12(2), 67. https://doi.org/10.1016/j.ihe.2016.03.001

Costa Martínez, J. (1911). Agricultura armónica (Expectante, popular). Madrid: Banco de España.

Crumbaugh, J. (2007). El turismo como arte de gobernar: los felices sesenta del franquismo. In M. Del Rey Reguillo (Ed.), Cine, imaginario y turismo (pp. 147-175). Valencia, España: Tirant lo Blanch.

De la Cal, L. (2015). Laponia en el corazón de España. El Mundo. Retrieved from https://tinyurl.com/ y3nxqzmk

Del Molino, S. (2016). La España vacía. Viaje por un país que nunca fue. Madrid: Turner Publicaciones, colección Noema.

Dubert, I. (1998). Mundo urbano y migraciones campo-ciudad en Galicia, siglos XVI-XIX. Boletín de la Asociación de Demografía Histórica, XVI(II), 39-86.

Dubert, I. (2002). Las dinámicas demográficas de las pequeñas villas gallegas a finales del Antiguo Régimen. Obradoiro de Historia Moderna, (11), 61-100. https://doi.org/10.15304/ohm.11.558

Eiras, A., \& Rey, O. (1994). Migraciones internas y medium distance en la Península Ibérica, 1500-1900. Santiago de Compostela: Xunta de Galicia-C.I.D.H.

Esparcia, J., Martínez-Puche, \& A. Querol, V. (2020). Reflexiones en torno al medio rural y la despoblación: La necesidad de superar la vieja política y avanzar hacia un enfoque transversal y una verdadera gobernanza multinivel. Revista de Treball, Economia i Societat, (98), 1-7. Retrieved from https://bit. ly/3bTgPbR

Fernández Santos, A. (1996). Nace un estilo. El País. Retrieved from https://tinyurl.com/yxhk65dj

Florencio, A., \& López Martínez, A. (2000a). Las migraciones estacionales agrarias en Andalucia anteriores al siglo XX. Boletín de la Asociación de Demografía Histórica, XVIII(1), 71-100.

Florencio, A., \& López Martínez, A. (2000b). El trabajo asalariado en la agricultura de la Baja Andalucía. Siglos XVIII y XIX. Historia Agraria, 21, 99-126.

García Barbancho, A. (1967). Las migraciones interiores españolas. Estudio cuantitativo desde 1900. Madrid, España: Instituto de Desarrollo Económico.

García Marcos, E. (18 octubre 2019). Un grupo de expertos propone 10 medidas para frenar la despoblación rural. Hosteltur. Retrieved from https://tinyurl.com/y6od5j32

García-Delgado, F. J. (2009). Industrias Cárnicas, Territorio y Desarrollo en Sierra Morena: la transformación del cerdo ibérico en las Comarcas de Jerez de los Caballeros, Llerena y Azuaga (Badajoz), la Sierra, el Andévalo Occidental y el Andévalo Oriental (Huelva), la Sierra Norte (Sevilla) y Los Pedroches (Córdoba), (Tesis doctoral). Universidad de Huelva, Huelva. España.

Gómez Alonso, R. (2006). El turismo no es un gran invento: aperturismo y recepción del ocio y consumo a través del cine español de los 60. Revista Área Abierta, (15), 1-10. Retrieved from http://hdl.handle. net/10115/3227

Gómez, A., \& Poyato, P. (2010). Profundidad de campo. Más de un siglo de cine rural en España. Madrid, España: Luces de Gálibo.

González Portilla, M., \& Zarraga, K. (Eds.) (1996). Los movimientos migratorios en la construcción de las sociedades modernas. Bilbao: Universidad del País Vasco.

González Requena, J. (1988). Apuntes para una historia de lo rural en el cine español. In C. Aguilar (Ed.), El campo en el cine español (pp. 13-27). Banco de Crédito Agrícola / Filmoteca Española.

Gozálvez Pérez, V., \& Martín-Serrano, G. (2018). El censo de la población de España de 1860: Notas de propedéutica sobre la población ocupada. Cuadernos de Geografía, 100, 59-88. Retrieved from https:// core.ac.uk/download/pdf/162130484.pdf 
Gubern, R. (2007). Lo rural, dentro y fuera del campo. En P. Poyato (Ed.), Lo rural en el cine español (pp. 15-34). Diputación de Córdoba y Ayuntamiento de Dos Torres.

Heredero, C. F., \& Reviriego, C. (2009). Memoria de un desafío. Entrevista a Montxo Armendáriz. Cahiers du Cinema (pp. 10-21), Especial n. ${ }^{\circ}$ 8, Tasio XXV Aniversario.

Hortelano Mínguez, L.A. (2008). Estrategias para atajar la despoblación en Castilla y León: Políticas de cohesión y redes de cooperación. En A. Martínez-Puche, J.P. Salas Argueros, J. Sánchez Navas \& C. Cortés Samper (Coords.), Sostenibilidad en los espacios rurales. Proyectos europeos, herramientas participativas, experiencias municipales y territoriales en España (pp. 63-86). Universidad de Alicante: Servicio de Publicaciones.

Izquierdo Vallina, J. (2016). La conservación natural de la naturaleza. Oviedo, España: Editorial KRK.

Leal, J. L., Leguina, J., Naredo, J. L., \& Tarrafeta, L. (1986). La agricultura en el desarrollo capitalista español (1940-1970). Madrid: Siglo XX.

Leinen, F (2009). Hola, estáis en vuestra casa: la negociación de conflictos culturales, étnicos y de género en Flores de otro mundo de Icíar Bollaín. Iberoamericana, 9(34), 89-101. https://doi.org/10.18441/ ibam.9.2009.34.89-101

Mainer, J.C. (1972). Literatura y pequeña burguesía en España. Madrid. España: EDICUSA.

Marcos, M.C. (2015). Estética e ideología en Surcos. España contemporánea: Revista de literatura y cultura, 24-25(2-1), 205-221. Retrieved from https://kb.osu.edu/bitstream/handle/1811/77804/EC_V24N2 V25N1-2_205.pdf

Marín, K. (1985). "Caravana de mujeres" para los solteros de Plan. El País. Retrieved from https://tinyurl. com/y3exgxx7

Morin, E. (1970). Cultura de masas en el siglo XX. El espíritu del tiempo. Río de Janeiro, Brasil: Forense.

Moyano, E. (2016). La piel quemada. Cine y emigración. Madrid. España: Ediciones de la Torre.

Otero Carvajal, L. (2010). Madrid de Capital a Metrópoli. Sociedad y espacio urbano en el Madrid del siglo XX (pp. 10-33). Madrid: Ayuntamiento de Madrid - Fundación Caja Madrid.

Peris Llorca, J. (2007). Si la ciudad no es para mí, ¿podría usted decirme dónde queda el campo? Una lectura de la película de Pedro Lazaga 1965. En J. Martí Contreras (Coord.), Actas del I Congreso Internacional de Lengua, Literatrua y Cultura Española: la didáctica para extranjeros (pp. 363-375). Onda, España: JMC.

Quintana, A., (2017). La piel quemada y la cuestión de la inmigración interior durante el franquismo. En E. Bou y J. Zarco (Eds.), Fronteras y migraciones en ámbito mediterráneo (pp. 133-145). Edizioni Ca'Foscari. http://doi.org/10.14277/6969-208-6/RiB-7-9

Reher, D. (1999). La historia de la familia en España: crónica de un campo en auge. Berceo, 137, 11-24.

Reques Velasco, P. (2017). La transición territorial. Cambios en las estructuras demo-espaciales en España (1900-2011): un análisis de base municipal. In J. D. Sempere Souvannavong y E. Cutillas Orgilés (Eds.), La población en España: 40 años de cambio (1975-2015) (pp. 67-132). Sant Vicent del Raspeig, España: Publicaciones de la Universidad de Alicante.

Robertson, R. (2002). Glocalization: Time-Space and Homogeneity-Heterogeneity. In M. Featherstone, S. Lash \& R. Robertson (Eds.), Global Modernities (pp. 25-44). London, UK: Sage. https://doi. org/10.4135/9781446250563.n2

Rodrigo Alsina, M. (1995). Los modelos de la comunicación. Madrid, España: Tecnos.

Rodríguez Galdo, Ma X., Freire Esparís, M. P. \& Prada Castro, A. (1999). Mujeres que emigran, mujeres que permanecen. Contribución a un estudio de la relación entre mujeres, economía campesina y emigración. Galicia, 1880-1930. Arenal. Revista de Historia de las Mujeres, (6), 265-294. Retrieved from https://revistaseug.ugr.es/index.php/arenal/article/view/16931

Roquer, S., \& Blay, J. (2008). Del éxodo rural a la inmigración extranjera, el papel de la población extranjera en la recuperación demográfica de las zonas rurales españolas (1999-2006). Scripta Nova. Revista Electrónica de Geografía y Ciencias Sociales, XII, 270. Retrieved from https://revistes.ub.edu/ index.php/ScriptaNova/article/view/1553 
Roquer, S., \& Blay, J. (2017). Evolución demográfica e inmigración extranjera en las zonas rurales españolas: Del Boom a la crisis. In J.D. Sempere \& E. Cutillas (Eds.), La población en España. 40 años de cambio (1975-2015) (pp.157-180). Alicante: Universidad de Alicante.

Sánchez Navas, J. (2012). Relaciones entre cine y mundo rural. Delimitación Metodológica del campo de estudio. En A. Martínez-Puche, S. Martínez-Puche y A. Prieto Cerdán (Eds.), Territorios de cine. Desarrollo local, tipologías turísticas y promoción (pp. 189-198). Alicante, España: Universidad de Alicante.

Sánchez Vidal, A. (1987). Florián Rey y las dos versiones de La Aldea Maldita. Artigrama, 4, 309-324.

Sarasúa C. (1994). Las emigraciones temporales en una economía de minifundio: Los Montes de Pas, 1758-1888. Boletín de la Asociación de Demografía Histórica, XII (2/3), 163-179.

Scholz, A. (2005). Der zeitgenössische spanische Autorenfilm zwischen Industrie und Kunst. Berlin, Deutsch: WVB.

Silvestre Rodríguez, J., \& Serrano Asenjo, E. (2012). La representación en el cine de la integración de los inmigrantes rurales en las ciudades: el pesimismo de Surcos (1951). AGER, Revista de Estudios sobre Despoblación y Desarrollo Rural, (12), 91-116. Retrieved from http://ruralager.org/wp-content/ uploads/Ager-12_3.pdf

Silvestre, J. (2010). Las migraciones interiores en España: 1860-2007. En Historia y política: Ideas, procesos y movimientos sociales, (23), 113-134. Retrieved from https://recyt.fecyt.es/index.php/Hyp/article/ view/44425

Sojo Gil, K. (2011). Éxodo rural y emigración al Madrid de los cincuenta: el caso de Surcos (1951), de José Antonio Nieves Conde. Quaderns de Cine, (6), 103-113. https://doi.org/10.14198/QdCINE.2011.6.10

Spanish Statistical Office [INE]. (1950). Retrieved from https://www.ine.es/dyngs/INEbase/en/ listaoperaciones.htm

Verón, E. (1987). La semiosis social. Fragmentos de una teoría de la discursividad. Barcelona, España: Gedisa.

Vilarós, T. (2002). Cine y literatura en la España de los sesenta: Testimonio de un primer proceso de desideologización. En N. Mínguez (Ed.), Literatura española y cine (pp. 193-206). Madrid: Complutense.

Zumalde Arregi, I. (1999). Los sonidos de la reconciliación. Estudio comparativo de dos versiones de "La aldea maldita" de Florián Rey. Cuadernos de la Academia, (5), 455-466. Retrieved from https://www. biblioteca.org.ar/libros/89867.pdf

Zunzunegui, S. (2005). Las vetas creativas del cine español. En P. Poyato (Comp.), Historia(s), motivos, y formas del cine español (pp. 9-21). Córdoba, España: Plurabelle. 